\title{
FISHERY STATUS OF THE STRIPED MULLET (PISCES: MUGILIDAE) FROM BARDAWIL LAGO0N, EGYPT I- AGE AND GROWTH OF MUGIL CEPHALUS
}

\author{
Azza A. El-Ganainy ${ }^{1}$, Mostafa E.T. ${ }^{2}$ and Omran M. A.A. ${ }^{2}$ \\ 1- National Institute of Oceanography and Fisheries, Suez Branch, P.O. \\ Box182, Suez, Egypt.E-mail address: azzaelgan@yahoo.com \\ 2-General Authority for the Development of Fish Resources, Department \\ of Bardawil Lagoon.
}

Key words: Mugil cephalus, age and growth, length frequency analysis, Bardawil lagoon.

\section{ABSTRACT}

This study deals with age determination of the striped mullet Mugil 1 cephalus collected from Bardawil Lagoon during four successive fishing seasons (1995 to 1998). The scale reading and length frequency analysis show that the catch of $M$. cephalus consists of 6 year classes. Age groups I and II represent the bulk of the catch. The growth parameters were determined from both length frequency and length-atage data. The estimated parameters based on length -at-age data were $L_{\infty}=74.164 \mathrm{~cm} ., \mathrm{K}=0.246 \mathrm{Y}^{-1}$ and $\mathrm{t}_{\mathrm{o}}=-0.969$ The similarity of the estimated growth parameters is reflected in the small range of the growth performance index $(\varphi)$, which indicates the compatibility of the two methods for the assessment of this species. The length weight relationship was calculated for each season separately and the mean resultant formula was $W=0.01547 \mathrm{~L}^{2.8558}$.

\section{INTRODUCTION}

Mullets are one of the most valuable resources in Bardawil lagoon, they constitute more than $40 \%$ of the lagoon production. The catch statistics show that the striped mullet production in Bardawil lagoon is variable, it is fluctuated between 140 tons and 523 tons during the last ten years. Mullets are fished in Bardawil lagoon with 
two fishing gears namely veranda (Bouss) and Dabba which depends on trammel nets.

The species composition of the mullets in the lagoon catch is composed of Mugil cephalus, Liza ramada, Liza aurata, Liza saliens and Chelon labrosus of which Mugil cephalus is the most abundant species contributing more than $50 \%$ of the mullet species.

Most of the fisheries studies on the lagoon concerned its management using MSY ( Pisanty, 1981; Bebars et al, 1992 and Breikaa, 1997) . A little attention was given to the species population dynamics (Ben Tuvia, 1979 and Bebars, 1986). This contribution is the first in a series to study the population dynamics of the striped mullet in Bardawil lagoon for the proper assessment and management of this valuable resource.

\section{MATERIALS AND METHODS}

\section{Study area:}

Bardawil lagoon (Fig. 1) lies between $31^{\circ} 03^{-} \& 31^{\circ} 14^{\circ} \mathrm{N}$ and E $32^{\circ} 40^{-} \& 33^{\circ} 30^{-} \mathrm{E}$ in the northern part of Sinai Peninsula, Egypt. The lagoon is separated from the Mediterranean Sea by a sandy bar with two narrow inlets. It is considered as a natural depression with a depth of $1-3 \mathrm{~m}$. The bottom of the lagoon is sandy along its shores, silt-muddy in the deepest part. The rest of the area is composed of muddy-sandy substrate. Most of the bottom is covered by the sea grass Ruppia $s p$. The salinity is 45 to $55 \mathrm{ppt}$ and the water temperature ranges from $12.7^{\circ} \mathrm{C}$ in January to $30.5^{\circ} \mathrm{C}$ in June (Pisanty, 1981). The fishing is seasonal, starts from the beginning of May to the end of December.

\section{Collection of data:}

Monthly samples of Mugil cephalus were collected from the commercial catch of the two landing sites in Bardawil lagoon, from the fishing season 1995 to 1998 . The data were based on fish samples caught by the different gears (Veranda and Dabba) operating in the Lagoon.

Each sampled fish were measured from the tip of the snout to the end of the caudal fin (total length) to the nearest $\mathrm{cm}$ and weighed to the nearest gram for the whole period of sampling. For the samples of the 1995 fishing season, scales were collected from representative subsamples and preserved in special envelops for the purpose of age determination. 


\section{Length-at-age data:}

Length-at-age data were based on the scale reading of about 585 specimens. The scales were cleaned, dried and bounded tightly between two glass slides, then examined using a Nikon zoom stereomicroscope. The total scale radius and each annulus radius were measured to the nearest $0.001 \mathrm{~mm}$. The fish length-scale radius relationship was determined and the constants of the relationship were calculated by the least square regression method. Length-at-age were back-calculated according to Lee's (1920) equation.

Length frequency analysis:

The collected monthly length frequency samples were grouped into $2 \mathrm{~cm}$ classes, and analyzed by adopting Bhattacharya (1967) method incorporated in the FiSAT routin of programs (Gayanilo et al., 1995). For the final decomposition of the composite distribution into normal distributions, the samples were pooled as seasonal ones for the separation of annual age groups or cohorts.

Growth estimates:

A preliminary estimate of the von Bertalanffy growth parameter ( $\left.\mathrm{I}_{\infty}\right)$ was based on the method of Wetherall (1986) as modified by Pauly (1986), where the monthly length frequency data were raised to the monthly total catch for the four analyzed fishing seasons. The weight of the samples was estimated using the length weight relationship derived from samples of $3999,8461,3261$ and 2568 specimens for the successive fishing seasons respectively. A full complement of growth parameters ( $\mathrm{L}_{\infty} \mathrm{K}$ and $\mathrm{t}_{0}$ ) was obtained using the mean back-calculated length-at-age and the mean assigned lengths at age derived from Bhattacharya method, as treated by the least squares method (Gayanilo et al., 1995).

\section{RESULTS AND DISCUSSION}

\section{Length weight relationship:}

The length weight relationship is required in population dynamics and fisheries stock assessment, since the rate of increase in weight reflects how the ecological factors of a habitat affect the fish in which it lives, particularly the amount of food available (Le Cren, 1951). The mathematical relationship between length and weight in 
most fish can be described by a formula of the type $W=a L^{b}$ where $\mathrm{W}$ is the fish weight, $\mathrm{L}$ is the fish length and $\mathrm{a}$ and $\mathrm{b}$ are constants. For the analysis of length weight relationship of Mugil cephalus, the least square method was applied for the samples of each season separately and the results of the correlation coefficient and the constants ( $a$ and $b$ ) are given in Table (1). The analysis showed that the mean length in the catch is gradually decreased from $31.94 \mathrm{~cm}$ in the fishing season 1995 to $30.92 \mathrm{~cm}$ in 1996 and $30.40 \mathrm{~cm}$. during 1997 then declined to be $28.13 \mathrm{~cm}$ during 1998 .

Bebars (1986) estimated the length weight relationship for $M$. cephalus in Bardawil lagoon as W $=0.0182 \mathrm{~L}^{2.8174}$ which is comparable to the results obtained in the present study.

\section{Age determination:}

The scales of $M$. cephalus proved to be the most reliable hard structure for age reading, since the increase in size of fish is accompanied by an increase in the number of annuli and the high degree of correlation $(\mathrm{r}=0.93332)$ between size of fish and the scale radius denotes that as the fish grows, the scale increase in size.

The relation between the total fish length and the anterior scale radius was determined for 585 specimens ranging in total length from 14.0 to $64.0 \mathrm{~cm}$. The resultant relationship is linear and can be represented as:

$$
\mathrm{L}=6.2381+2.2133 \mathrm{~S}
$$

Where $L$ is the total fish length in $\mathrm{cm}$ and $\mathrm{S}$ is the scale radius in $\mathrm{mm}$ with the correlation coefficient of 0.93332 .

The fish length corresponding to each scale annulus was calculated according to Lee's (1920) equation and the back-calculated lengths at the end of the different years of life are given in Tabie (2). Thus it was clear that the maximum increment is observed at the first year of life, whereas in the following years the rate of growth slows down. During the first three years of life, the striped mullet reached a length of $46.45 \mathrm{~cm}$ and in the following three years the total length increased by only $12 \mathrm{~cm}$.

Bebars (1986) estimated the longevity of the $M$. cephalus from Bardawil lagoon as five years old for females and three years old for males. The back-calculated lengths recorded by him were 29.01, 43.03, $54.32,61.59$ and $66.27 \mathrm{~cm}$ for females and $27.36,36.84$ and $42.99 \mathrm{~cm}$ for males respectively. The lengths of the first year of life were the only ones comparable with the present work. 
FISHERY STATUS OF THE STRIPED MULLET (PISCES: 51 MUGLIDAE) FROM BARDAWIL LAGOON, EGYPT.

\section{Length frequency analysis:}

The monthly length frequency distributions are represented in Figures (2 \& 3) for the four successive fishing seasons from May 1995 to November 1998. The sampling during the fishing season 1997 was restricted in four months. It was clear that the frequencies of the small lengths $<16.0 \mathrm{~cm}$ appear in June and July which indicated that recruitment to the fishery occurs through these months.

The seasonal distributions were analyzed by Bhattacharya (1967) method, which provided a maximum of 6 age groups for the samples of the three fishing seasons 1995 to 1997 and 5 age groups for the samples of 1998 (Fig. 4). The identified age groups were assigned to mean lengths of the component distributions in each length composition sample. The assigned lengths at age for each group with their predicted lengths and the statistical residual are given in Table (3). It shows the good agreement between the mean lengths at age for the samples of 1995 and 1996 and the corresponding back-calculated lengths based on scale reading. While the assigned lengths at 1997 and 1998 tend io be smaller, which may be due to the increase of the frequencies of the small-size classes and the disappearance of age group 6 in the fishing season 1998. This could be an indication of growth and recruitment over-fishing:

\section{Age composition:}

The age composition of the striped mullet Mugil cephalus was studied regardless of sex and the maximum age was found to be 6 years old. The percentage of the different age groups was 10.77, 38.97, $34.36,12.14,2.39,0.85$ and 0.51 percent for age groups $0, \mathrm{I}, \mathrm{II}, \mathrm{III}, \mathrm{IV}$, $\mathrm{V}$ and VI respectively. Figure (5) shows that age groups I and II are the dominant groups in the catch. Therefore, it is reasonable to assume that individuals of Mugil cephalus are fully recruited to the fishery in Bardawil lagoon at an age of one year. The results of Babers (1986) also indicated that the bulk of the striped mullet catch in the lagoon consists of age group one.

\section{Growth estimates:}

The von Bertalanffy (1938) growth parameters ( $\mathrm{L}_{\infty}, \mathrm{K}$ and $\mathrm{t}_{0}$ ) of $M$. cephalus were estimated by two different methods. The least squares method (Gayanilo et al., 1995) was applied for the length-at age data, as well as for the assigned mean lengths derived from Bhattacharya (1967) method. The Wetherall (1986) method for the 
estimation of $L_{\text {oo }}$ and $Z / K$ was adopted for the raised length composition of the seasonal samples, the estimated parameters are given in Table (4) and the theoretical growth curve for the four successive fishing seasons are illustrated in Figure (6). The results show that the Los estimates are in gradual decrease recording its minimum value in the fishing season 1998, this can be regarded to the small maximurn recorded length $(52.2 \mathrm{~cm})$ during that season.

Comparison of the results of the present work with that preceded in literature is summarized in Table (5). The estimate of the growth parameters by different authors in various localities, revealed that, there is no definite growth pattern for the parameters estimated by different authors and the results diverge between different authors in different areas. These differences might be explained by the different methods applied for age determination (Oren, 1981); also these differences could be explained by the worldwide distribution of this species, and its different survival strategies (Ibanez Aguirre, 1999). However, the results of the present study are comparable to those oblained by Erman (1959) in Turkey (Mediterranean Sea), Thompson (1963) in Australia and Bebars (1986) in Bardawil lagoon.

\section{Conclusion}

The back-calculated lengths of Mugil cephalus based on the scale reading and the assigned lengths at age derived from length frequency analysis were found to be comparable, The growth parameters obtained from length at age data were very similar to those obtained from length frequency data, indicating compatibility of the two data sets and methods applied. This was confirmed by the values of the growth performance index $\left(\Phi=\log 10 K+\log 10 L_{\infty}\right)$ developed by Pauly and Munro (1984) and given in Table (4). The value of this index as stated by Pauly and Munro is comparable inspite of the presence of differences between different populations.

Therefore, the length frequency data are cosidered sufficient, for this relatively shot-lived species to obtain reliable growth parameter estimates, and that further population dynamic studies should be undertaken to assess the striped mullet resource in Bardawil lagoon. 
FISHERY STATUS OF THE STRIPED MULLET (PISCES: 53 MUGLIDAE) FROM BARDAWIL LAGOON, EGYPT.

\section{REFERENCES}

Annala, J. H. (comp.) (1994). Report from the fishery assessment planar, May 1994: stock assessment and yield estimates. Unpublished report held in MAF Fisheries Greta Point library, Wellington. $242 p$.

Bebars, M. I. (1986). Second scientific report on the stock assessment management of the Bardawil lake fisheries submitted to the Academy of Scientific Research and Technol., December 1986.

Bebars, M. I.; Ahmed, O. K. and Briekaa, M. I. (1992). Fisheries management of Bardawil lagoon (North Sinai, Egypt). Project of fish resources development in Bardawil lagoon. Final report Academy of Scientific Research and Technol., $93 p$.

Ben-Tuvia, A. (1979). Studies of the population and Fisheries of Sparus aurata in the Bardawil lagoon. eastern of Mediterranean. Invest. Pesq. Barc., 43(1): 43-67.

Betralanffy von, L. (1938). A quantitative theory of organic growth. Hum. Biol., $10(2)$ : 181-213.

Bhattacharya, C. G., (1967). A simple method of resolution of a distribution into gaussian components. Biometrics, 23(1): 115-135.

Breikaa, M. I. M. (1997). Fisheries management studies on the Bardawil lagoon, Northern Sinai, Egypt. Egypt. J. Aquat. Biol. \& Fish., l(2): 291-307.

Cech, J. J. Jr. and Wohlschlag, D. E. (1975). Summer growth depression in the striped mullet, Mugil cephalus. Contrib. Mar. Sci., 19: 92-100.

Diaz P. E. and Hernandez, S. (1980). Crecimiento, reproduccion y habitos alimenticios de la lisa Mugil cephalus en la Laguna 
de San Andres, Tamps. An. Esc. Nal. Cienc. Biol., Mexico, 23:109-127.

Erman, F. (1959). Observation on the biology of the common grey mullet (Mugil cephalus). Proc. Tech. Pap. Gen. Fish. Counc. Mediterr., 5: 157 - 169.

Farrugio, H. (1975). Les muges (Poissons, Teleosteens) de Tunisie: repartition et peche. Contribution a leur etude system-antique et biologique. M.S. thesis, Universite des Sciences et Techniques du Languedoc. Montpellier, 316pp.

Gayanilo, F. C. Jr. ; Sparre, P. and Pauly, D. (1995). The FiSAT user's guide. FAO computerized information series fisheries, 99, ICLARM, DIFMAR, Rome.

Ibanez- Aguirre, A. L.; Gallardo-Cabello M. and Carrara, X. C. (1999). Growth analysis of striped mullet, Mugil cephalus, and white mullet, $M$. cureme (Pisces : Mugilidae), in the Gulf of Mexico. Fish. Bull:, 97: 861-872

Ih-Hsiu Tung, (1970). Studies on the fishery biology of the grey mullet Mugil cephalus, in Taiwan. P. 491-504. In J. C. Fast West Center Press. Honolulo.

Jingran, J. K. and Misra, I. L. (1962). Further-tagging experiments in Chilka-Lake, with special reference to Mugil cephalus Linnaeus. Indian J. Fish., 9(2): 129-197.

Le Cren, D. E. (1951). The length weight relationship and seasonal cycle in gonad weight and condition in the perch Perca fluviatilis. J. Anim. Ecol., 20(2): 201-219.

Lee, R. M. (1920). A review of the methods of age and growth determination in fishes by means of scales. Fish. Invest. Min. Agr. Fish. Ser., $2: 4(2): 1-23$.

Marquez, M. R. (1974). Observaciones sobre mortalidad total y cercimiento en longitud de la lisa (Mugil cephalus) en la laguna da Tamiahua, ver., Mexico. I.N.P. de Secretaria de Pesca, 15pp. 
FISHERY STATUS OF THE STRIPED MULLET (PISCES: $\quad 55$ MUGILIDAE) FROM BARDAWIL LAGOON, EGYPT.

Morovic, D. (1964). Contribution a la connaisance de la croissance annuelle de Mugil cephalus L. et Mugil chelo Cuv. Dans l'Adriatique. Acta adriatica, 11:195-204.

Oren, O. H. (1981). "Aquaculture of grey mullets." Cambridge Univ. Press. Cambridge, U. K., 507pp.

Pauly, D. (1979). Theory and management of tropical multispecies stocks : a review with emphasis on the southeast Asian demersal fisheries. ICLARM stud. Rev., I: 35p.

Pauly, D. (1986). On improving operation and use of the ELEFAN programs, part III. Correcting length frequency data for the effects of gear selection and/ or incomplete recruitment. Fishbyte, 4 (1):18-20.

Pauly, D. and Munro, J. L. (1984). Once more on the comparison of growth in fish and invertebrates. Fishbyte, 2(1): 21.

Pisanty, S. (1981). The fishery and management of the hypersaline lagoon of Bardawil. Stud. Rev. Gen. Fish. Counc. Mediterr., 58: 35-73.

Thompson, J. M. (1963). Synopsis of biological data on the grey mullet Mugil cephalus L. 1758. Fish. Synop. Div. Fish. Oceanogr. CSIRO, Aust., 1:1-75.

Wetherall, J. A. (1986). A new method for estimating growth and mortality parameters for length frequency data. Fishbyte., 4 (1): $12-14$.

Wijeyaratue, M. J. S. and Costa, H. H. (1987). Fishery seasonal abundance and mortality of grey mullets (Pisces: Mugilidae) in Negombo Lagoon, Sri Lanka. J. Appl. Icthyol., 3: 115-118. 
Table (1) Constants of length weight relationship for Mugil cephalus from Bardawil Lagoon collected from 1995 to 1998.

\begin{tabular}{|c|c|c|c|c|}
\hline Constant & 1995 & 1996 & 1997 & 1998 \\
\hline $\mathbf{a}$ & 0.01597 & 0.01450 & 0.01567 & 0.01547 \\
\hline $\mathbf{b}$ & 2.86883 & 2.86794 & 2.84480 & 2.85580 \\
\hline $\mathbf{r}^{2}$ & 0.90779 & 0.96168 & 0.93639 & 0.95480 \\
\hline $\mathbf{n}$ & 3999 & 8461 & 3261 & 2568 \\
\hline
\end{tabular}

Table ( 2 ) Mean observed, back-calculated lengths at the different years of life for Mugil cephalus from Bardawil lagoon.

\begin{tabular}{|c|c|c|c|c|}
\hline Age & No & $\begin{array}{c}\text { Range of observed } \\
\text { length }\end{array}$ & $\begin{array}{c}\text { Mean observed } \\
\text { length } \\
( \pm \text { SD) }\end{array}$ & $\begin{array}{c}\text { Back-calculated } \\
\text { length } \\
( \pm S D)\end{array}$ \\
\hline 0 & 63 & $14.9-25.8$ & $20.50 \pm 3.33)$ & $17.5(4.32)$ \\
I & 228 & $23.6-35.9$ & $30.61 \pm 4.24)$ & $28.56( \pm 3.45)$ \\
II & 201 & $34.6-46.6$ & $40.41 \pm 2.97)$ & $38.19(2.27)$ \\
III & 71 & $44.3-54.8$ & $49.75 \pm 2.76)$ & $46.45( \pm 2.23)$ \\
V & 14 & $51.8-57.5$ & $54.78( \pm 2.28)$ & $52.01 \pm 2.10)$ \\
IV & 5 & $54.0-62.3$ & $60.67(2.25)$ & $57.54(0.64)$ \\
VI & 3 & $60.2-64.0$ & $62.90(0.68)$ & $60.57(0.66)$ \\
\hline
\end{tabular}


Table (3) Back calculated lengths, assigned lengths at age obtained from Bhattasharya method and the corresponding pridected lengths and their residual for Mugil cephalus from Bardawil lagoon.

\begin{tabular}{|c|c|c|c|c|c|c|c|c|}
\hline \multirow[t]{2}{*}{ Year } & Method & \multicolumn{7}{|c|}{ Years of life } \\
\hline & & 0 & 1 & 2 & 3 & 4 & 5 & 6 \\
\hline $\begin{array}{l}1 \\
9\end{array}$ & Back-calculated & 17.50 & 28.56 & 38.19 & 46.45 & 52.01 & 57.54 & 60.57 \\
\hline 9 & Pridected & 17.15 & 28.47 & 38.43 & 46.22 & 52.32 & 57.08 & 60.80 \\
\hline 5 & Residual & 0.26 & 0.09 & -0.24 & 0.23 & -0.31 & 0.46 & -0.23 \\
\hline 1 & Assigned & 18.22 & 29.22 & 37.89 & 46.70 & 52.46 & 55.00 & 61.03 \\
\hline 9 & Pridected & 17.68 & 29.11 & 38.50 & 45.96 & 51.87 & 56.57 & 60.29 \\
\hline 5 & Residual & -0.28 & 0.12 & -0.61 & 0.74 & 0.59 & -1.57 & 0.74 \\
\hline $\begin{array}{l}1 \\
9\end{array}$ & Assigned & & 26.52 & 38.15 & 46.21 & 53.13 & 59.21 & 61.40 \\
\hline 9 & Pridected & & 26.46 & 37.99 & 46.69 & 53.26 & 58.22 & 61.97 \\
\hline 6 & Residual & & 0.03 & 0.16 & -0.47 & -0.13 & 0.20 & -0.57 \\
\hline $\begin{array}{l}1 \\
9\end{array}$ & Assigned & & 26.66 & 35.93 & 45.56 & 51.41 & 56.12 & 59.00 \\
\hline 9 & Pridected & & 26.27 & 36.95 & 45.05 & 51.19 & 55.84 & 59.37 \\
\hline 7 & Residual & & 0.39 & -1.02 & 0.51 & 0.22 & 0.28 & -0.37 \\
\hline $\begin{array}{l}1 \\
9\end{array}$ & Assigned & 13.00 & 24.03 & 32.42 & 41.00 & 47.33 & 50.00 & \\
\hline 9 & Pridected & 12.62 & 23.66 & 33.37 & 40.75 & 46.36 & 50.63 & \\
\hline 8 & Residual & 0.62 & 0.35 & -0.95 & 0.25 & 0.97 & -0.63 & \\
\hline
\end{tabular}


Table (4) Estimates of the von Bertalanffy growth parameters for Mugil cephalus according to the different methods used.( standerd error are given in brackets)

\begin{tabular}{|c|c|c|c|c|c|c|}
\hline Year & Method & $\mathfrak{L}_{\infty}$ & $k$ & $t_{0}$ & $\Phi$ & $r^{2}$ \\
\hline \multirow{4}{*}{9} & $\begin{array}{l}\text { Least squares method } \\
\text { for back-calculated lengths }\end{array}$ & $\begin{array}{l}74.164 \\
(2.283)\end{array}$ & $\begin{array}{l}0.246 \\
(0.021)\end{array}$ & $\begin{array}{l}-0.969 \\
(0.119)\end{array}$ & $\begin{array}{c}3.131 \\
(0.525)\end{array}$ & 0.9984 \\
\hline & Least squares for lengths & 74.613 & 0.231 & -1.138 & 3.11 & 0.9845 \\
\hline & & & & & & \\
\hline & Wetnerali & 72.792 & 0.229 & -0.575 & 3.084 & 0.9640 \\
\hline $\begin{array}{l}1 \\
9\end{array}$ & $\begin{array}{l}\text { Least squares for lengths } \\
\text { from Bhattacharya method }\end{array}$ & $\begin{array}{l}73.591 \\
(3.249)\end{array}$ & $\begin{array}{c}0.28 \\
(0.036)\end{array}$ & $\begin{array}{l}-0.595 \\
(0.156)\end{array}$ & $\begin{array}{l}3.181 \\
(0.613)\end{array}$ & 0.9956 \\
\hline 6 & Wetherall & 71.536 & 0.266 & -0.495 & 3.134 & 0.9680 \\
\hline $\begin{array}{l}1 \\
9 \\
0\end{array}$ & $\begin{array}{l}\text { Least squares for lengths } \\
\text { from Bhattacharya method }\end{array}$ & $\begin{array}{l}70.439 \\
(3.463)\end{array}$ & $\begin{array}{c}0.277 \\
(0.040)\end{array}$ & $\begin{array}{l}-0.686 \\
(0.183)\end{array}$ & $\begin{array}{c}3.138 \\
(0.549)\end{array}$ & 0.9945 \\
\hline 7 & Wetherall & 66.073 & 0.288 & -0.466 & 3.099 & 0.9630 \\
\hline $\begin{array}{l}1 \\
9 \\
9\end{array}$ & $\begin{array}{l}\text { Least squares for lengths } \\
\text { from Bhattacharya method }\end{array}$ & $\begin{array}{l}64.18 \\
(9.244)\end{array}$ & $\begin{array}{l}0.274 \\
(0.092)\end{array}$ & $\begin{array}{l}-0.681 \\
(0.359)\end{array}$ & $\begin{array}{c}3.052 \\
(0.641)\end{array}$ & 0.9790 \\
\hline 8 & Wetherall & 65.126 & 0.298 & $-0.45 t$ & 3.102 & 0.9980 \\
\hline
\end{tabular}


Table (5) Growth parameters of Mugil ceplsalus of Egypl (Bnrdawil Lagoon) and other localities

\begin{tabular}{|c|c|c|c|c|c|c|c|c|}
\hline Author & Locally & Method & Sex & Length & L & K & l. & $\Phi$ \\
\hline Eman, 1959 & Mediterranean, Turkey & Ooliths & Sp. & $\pi$ & 71.5 & 0.254 & & 3.11 \\
\hline Jingm \& Misfa, 1962 & India & Tagging & Sp. & & 140.0 & 0.150 & & 3.47 \\
\hline Thompson, 1963 & Australia & Scales & Sp. & $\mathrm{TL}$ & 72.7 & 0.230 & 0.006 & \\
\hline \multirow[t]{2}{*}{ Morovic, 1864} & Mediterranean, & & & & & & & \\
\hline & Yunoslavia & Scolos & Sp. & NG & 48.5 & 0.310 & & 2.86 \\
\hline \multirow[t]{2}{*}{ In-Hsiu Tung, 1970} & Tahwan & Scales & $\mathbf{M}$ & TL & 49.8 & 0.395 & 0.050 & 2.89 \\
\hline & & & $F$ & TL & 59.3 & 0.301 & -0.120 & 3.02 \\
\hline Marquez, 1974 & Mexico & Scales & Sp. & TL. & 51.0 & 0.340 & -0.114 & \\
\hline Cech \& Wohischlag. & & & & & & & & \\
\hline \multirow[t]{2}{*}{1975} & Texas, USA & Scales & $M$ & $T L$ & 40 & 0.367 & -0.480 & 2.77 \\
\hline & & & $F$ & $\mathrm{TL}$ & 42,2 & 0.327 & -0.700 & 2.77 \\
\hline \multirow[t]{2}{*}{ Famugio, 1975} & Mediterranean, Tunisia & Scales & $M$ & TL & 48.6 & 0.29 & & 2.04 \\
\hline & & & $F$ & $\pi$ & 54.6 & 0.2 & & 2.78 \\
\hline Pauly, 1979 & Meditertanean, Turkey & $\begin{array}{l}\text { Lenglh } \\
\text { Frequency }\end{array}$ & Sp. & TL & 105 & 0.11 & & 3.08 \\
\hline $\begin{array}{l}\text { Diaz \& Hernandez, } \\
1880\end{array}$ & Mexico & Scales & So. & $T L$ & 56.6 & 0.19 & -0.213 & \\
\hline Bebers, 1986 & Bardawil Lagoon & Scales & $\stackrel{M}{F}$ & $\frac{\pi}{\pi}$ & $\begin{array}{r}54.3 \\
79.22\end{array}$ & $\begin{array}{l}0.433 \\
0.341\end{array}$ & $\begin{array}{l}-0.618 \\
-0.337\end{array}$ & \\
\hline $\begin{array}{l}\text { Wrieyaratue \& Costa, } \\
1887\end{array}$ & Sril.anka & Scales & Sp. & $T L$ & 89.7 & 0.094 & & 2.06 \\
\hline \multirow[t]{2}{*}{ Annala, 1994} & Newzogland & Scales & $\mathbf{M}$ & FL & 35.8 . & 0.47 & & 2.78 \\
\hline & & & $\mathbf{F}$ & FL & 40.1 & 0.45 & & 2.86 \\
\hline \multirow[t]{2}{*}{$\begin{array}{l}\text { lbanez Aguitre el al, } \\
1999\end{array}$} & Mexico & Otoliths & $M$ & $\mathrm{TL}$ & 60.4 & 0.11 & -2.978 & \\
\hline & & & $\mathbf{F}$ & $\mathbf{T}$ & 62.3 & 0.11 & -2.67 & \\
\hline Present study & Bsidawil Lagoon & Scales & Sp. & $\mathrm{n}$ & 74.2 & 0.248 & -0.880 & \\
\hline
\end{tabular}




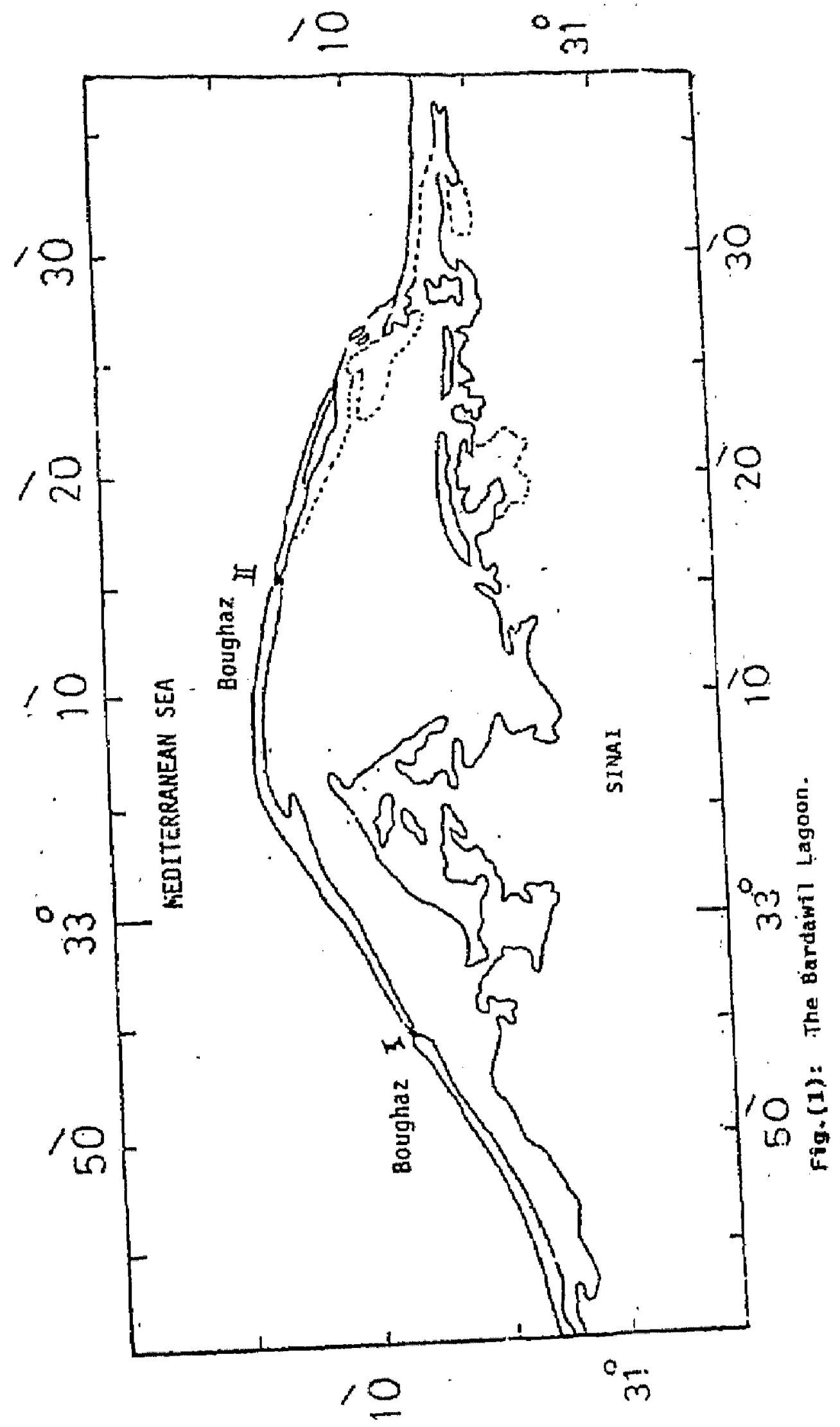



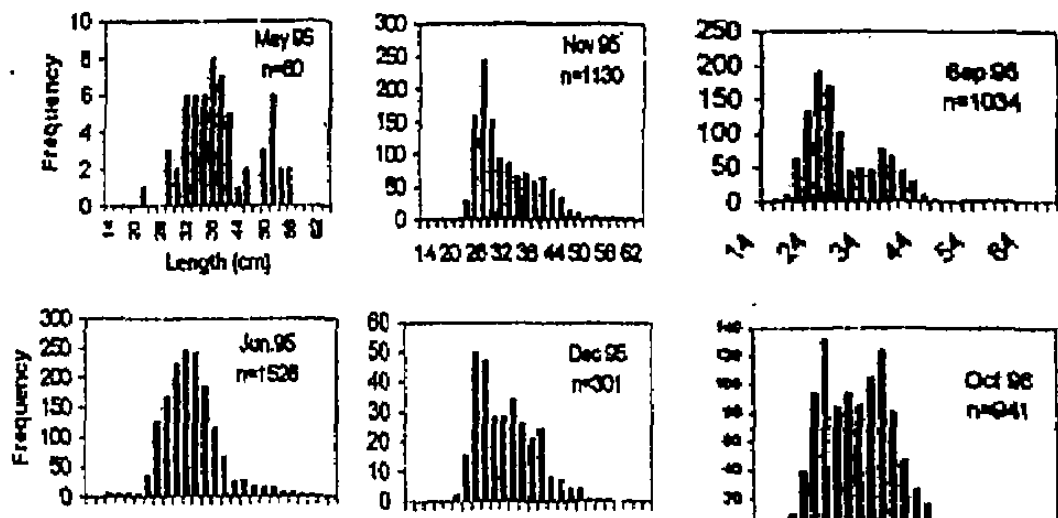

at it of to $6^{2}$

50 की की Lengeth (cm)
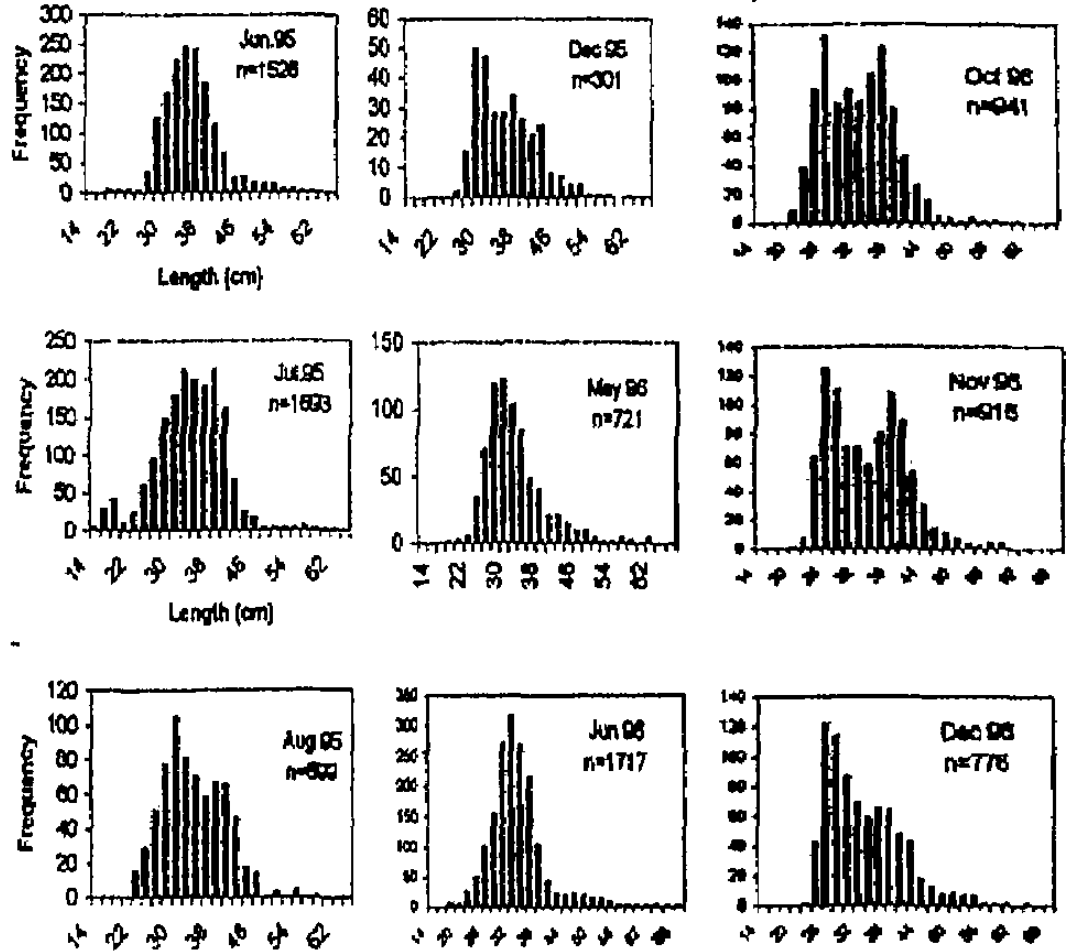

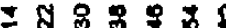
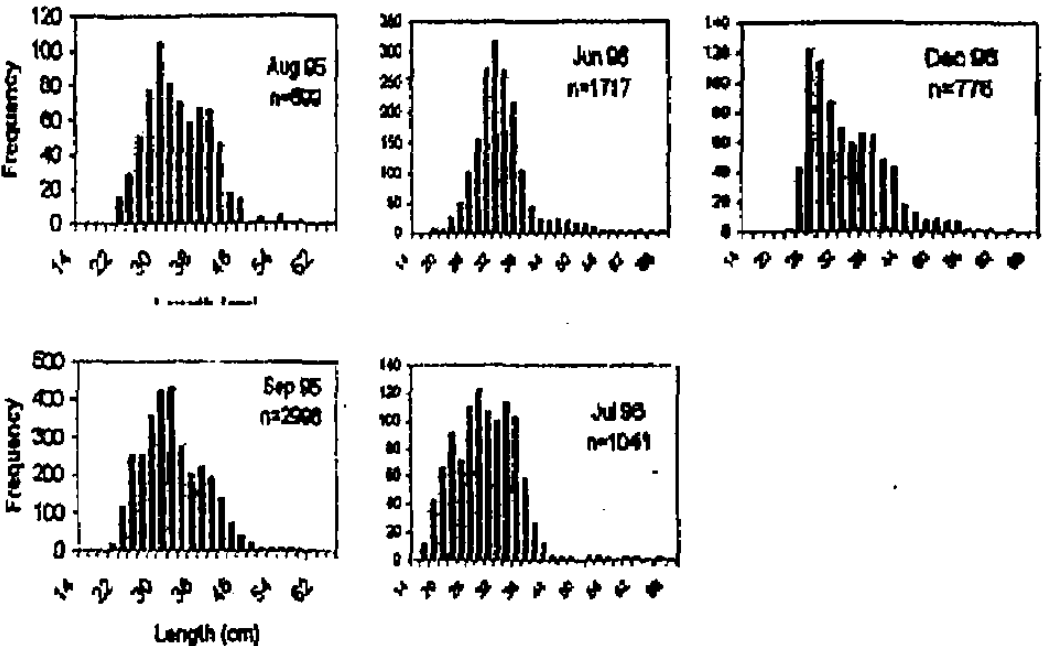

Lenth (cm)
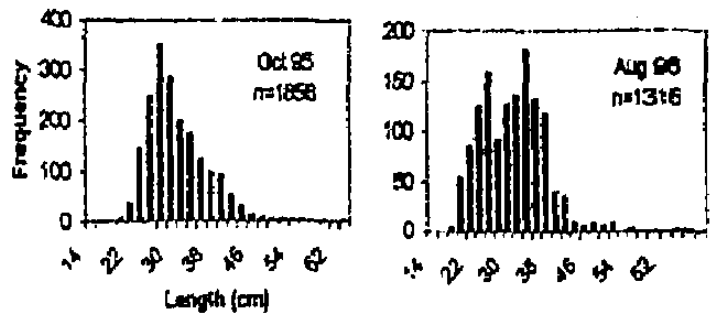

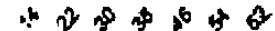

Fig (2) tength 'frequency distributions of Muxil cephalus from Bardawil lagoon during the fishing seasons 1995 and 1996. 

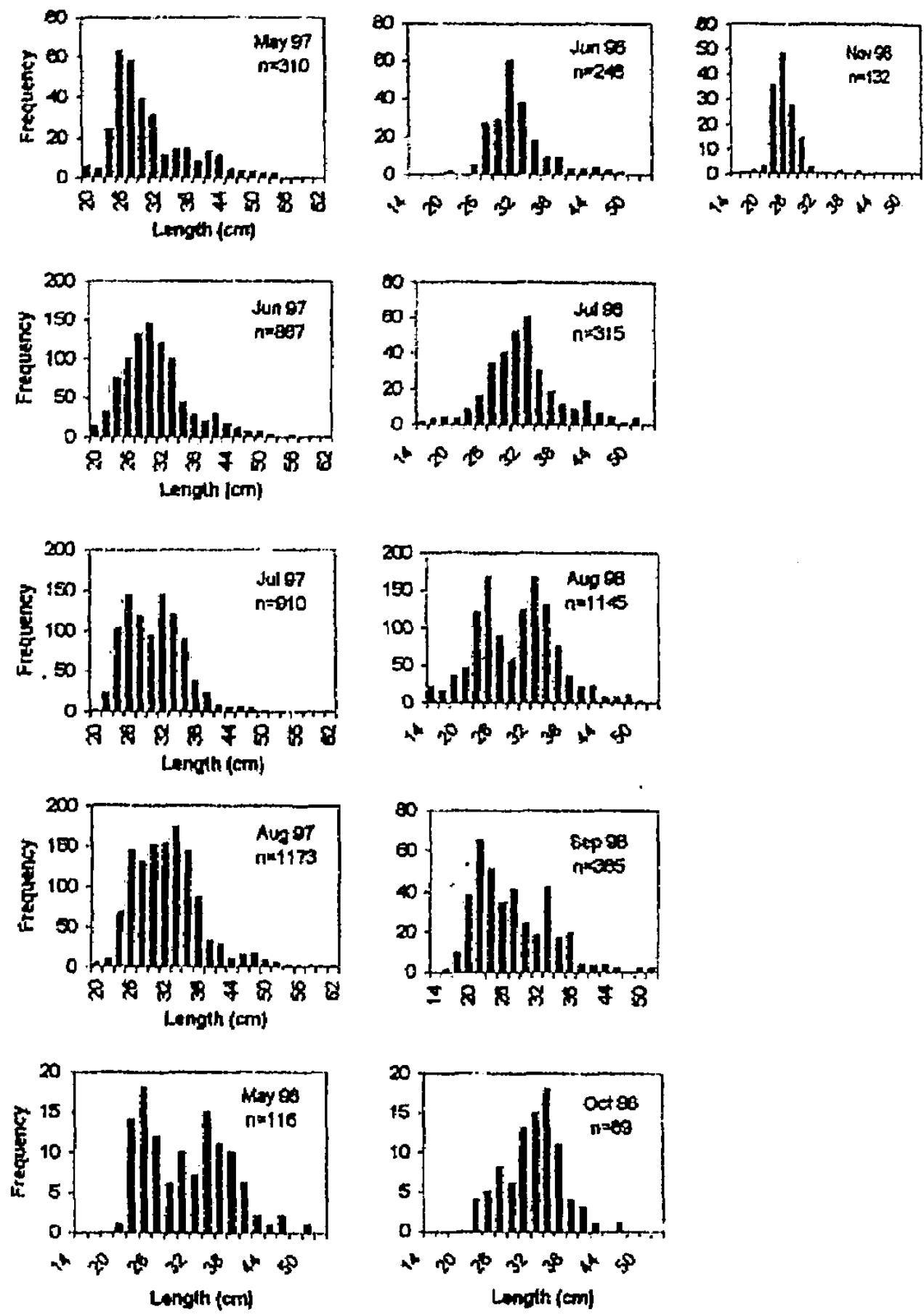

Fig (3) length frequency distributions of Mugil cephalus from Bardawil lagoon during the fishing seasons 1997 aud 1998. 

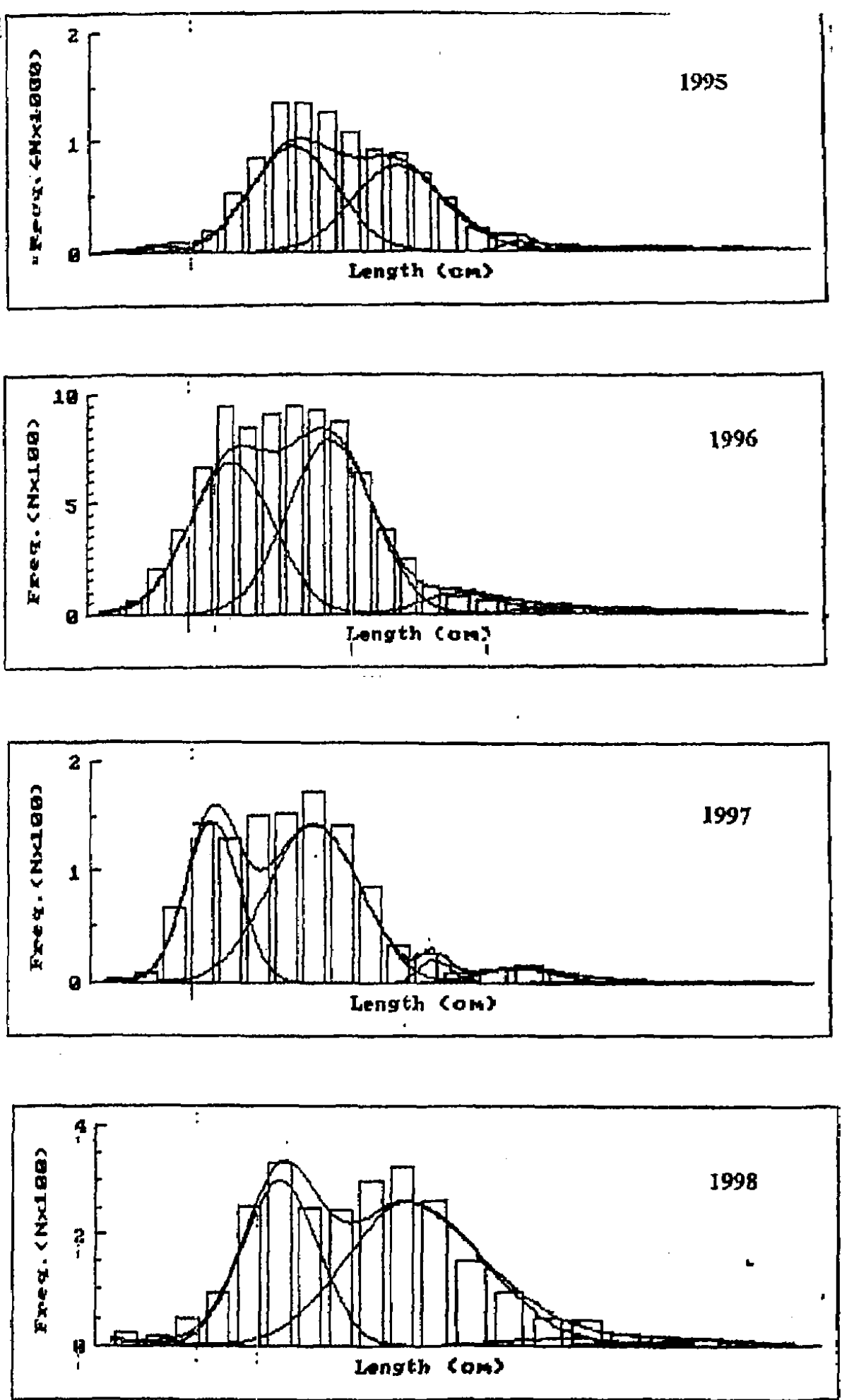

Fig (4) Seasonat length frequency distributions of Mugil cephalus with modal length groups as obtained from Bballisharya method. 


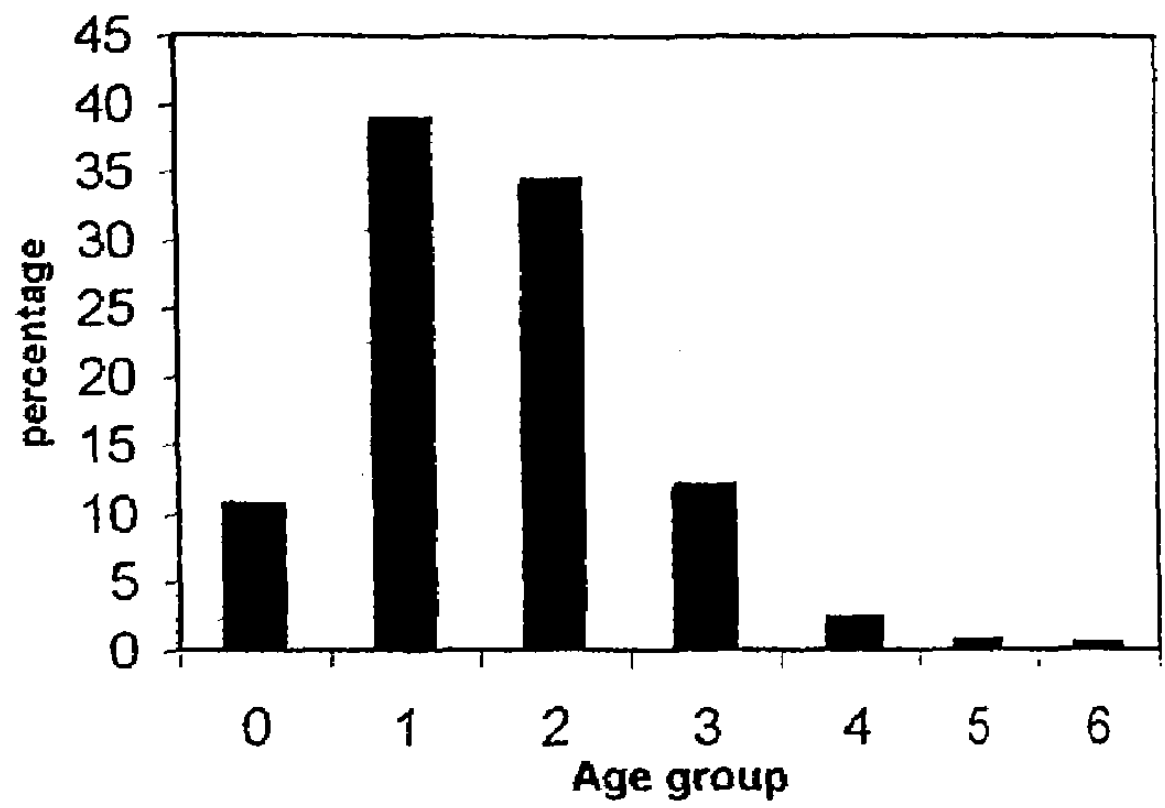

Fig (5) Age composition of Mugil cephalus in Bardawil lagoon

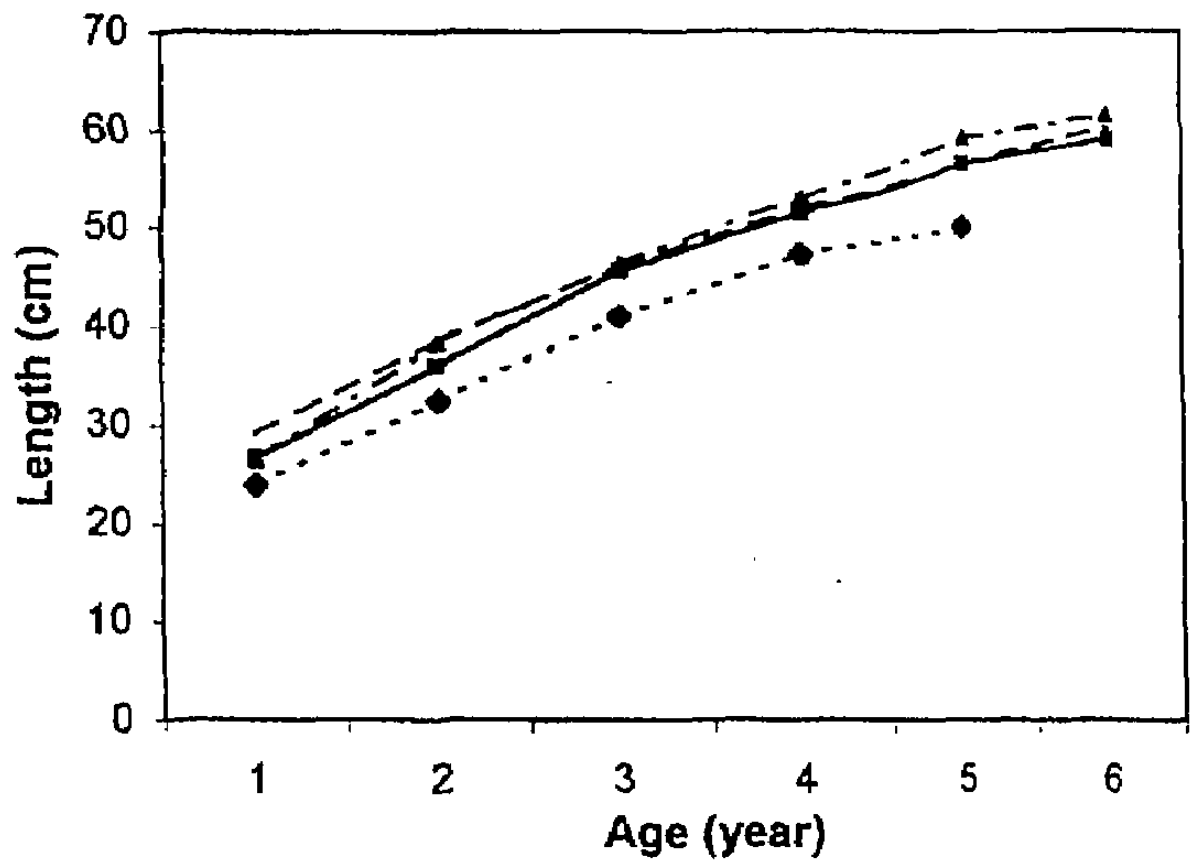

Fig (6) Theoretical growth curve of Mugil cephalus in four sucsessive years (1995-1998). 